\title{
Organization of fish assemblages in blackwater Atlantic Forest streams
}

\author{
Katharina Eichbaum Esteves ${ }^{1}$, Marcelo Horikoshi Candido Silva ${ }^{2}$, \\ Maressa Helena Nanini-Costa ${ }^{3}$ and Maria Letizia Petesse ${ }^{2}$
}

\begin{abstract}
This study aimed to determine whether fish species occupy different mesohabitats, as defined by specific criteria of substrate types in Atlantic Forest blackwater streams. We sampled fourteen coastal blackwater rivers along the coast of São Paulo State, Brazil, during the low-flow season (June-September/2016). For each stream, we selected three mesohabitat types (sand, leaf-litter and trunks) in a $100 \mathrm{~m}$ river stretch. We sampled 41 mesohabitats, 31 of which contained fish, resulting in 15 species. When multivariate analysis of variance (MANOVA) was applied to the mesohabitat abiotic variables, no significant differences were indicated between them. ANOSIM for species density and biomass and Redundancy Analyses (RDAs) for species density, biomass and fish community indexes showed similar patterns of community structure among mesohabitats. Nevertheless, fish biomass, diversity and richness were associated with such unique environmental features as low shading and shallow habitats. The observed dispersion among mesohabitats suggests that these communities are subject to some level of disturbance, which may affect the value of patches as refugia. Thus, the sharing of these mesohabitat patches among species may represent an opportunistic strategy to maximize the use of available resources for these low density populations living in these unique environments.
\end{abstract}

Keywords: Community structure, Leaf-litter, Mesohabitat, Spatial distribution, Substrate types.

O objetivo do estudo foi testar se espécies de peixes ocupam diferentes mesohabitats definidos por critérios específicos de tipos de substrato em riachos de águas pretas de Mata Atlântica. Durante a estação de baixa vazão (junho-setembro/2016), foram amostrados quatorze riachos costeiros de águas pretas no litoral de São Paulo, Brasil. Para cada riacho, selecionamos três tipos de mesohabitats (areia, folhiço e troncos) em um trecho de rio de $100 \mathrm{~m}$. Amostramos 41 mesohabitats, dos quais $31 \mathrm{com}$ peixes, resultando em 15 espécies. A análise de variância multivariada (MANOVA) aplicada às variáveis abióticas dos mesohabitats, não indicou diferenças significativas entre estes. A ANOSIM para densidade de espécies e biomassa e as Análises de Redundância (RDAs) para densidade de espécies, biomassa e índices da comunidade indicaram padrões semelhantes da estrutura da comunidade entre mesohabitats. No entanto, a biomassa, a diversidade e a riqueza de peixes estiveram associadas a características ambientais específicas tais como habitats rasos e sombreados. Os resultados sugerem que estas comunidades estejam sujeitas a certo nível de perturbação, o que afeta o valor dos mesohabitats como refúgios. Assim, a utilização dos diferentes mesohabitats entre as espécies pode representar uma estratégia oportunista para maximizar o uso de recursos por essas populações de baixa densidade que vivem nestes ambientes peculiares.

Palavras chave: Distribuição espacial, Estrutura de comunidades, Folhiço, Mesohabitats, Tipo de substrato.

\section{Introduction}

Different spatial scales are important in structuring fish communities, ranging from the influence of local processes, such as water quality, substrate, and channel morphology, to those at basin level, such as geology, soil type and use, topography, and climate (Wang et al., 2003). Fluvial sys- tems are dynamic mosaics of interconnected patches that influence biological communities, as asserted by the Patch Dynamics Concept (Pringle et al., 1988; Townsend, 1989), a model which is now considered to represent just one of the four distinct models of metacommunity dynamics (Leibold et al., 2004), of which disturbance seems to be a key component (Winemiller et al., 2010). Therefore, patches increase

\footnotetext{
${ }^{1}$ Centro de Pesquisa em Recursos Hídricos, APTA, Instituto de Pesca, Secretaria da Agricultura e Abastecimento do Estado de São Paulo. Avenida Francisco Matarazzo, 455, Água Branca, 05001-900 São Paulo, SP, Brazil. kesteves.ke@gmail.com, Dhttp://orcid. org/0000-0001-5123-9669 (corresponding author)

${ }^{2}$ Programa de Pós-graduação em Aquicultura e Pesca, APTA, Instituto de Pesca, Secretaria da Agricultura e Abastecimento do Estado de São Paulo. Avenida Francisco Matarazzo, 455, Água Branca, 05001-900 São Paulo, SP, Brazil; (MHCS) marcelo.horikoshi@gmail. com, Ohttp://orcid.org/0000-0002-5490-5425; (MLP) mlpetesse@gmail.com, @http://orcid.org/0000-0001-6094-671X

${ }^{3}$ Controle Analítico Análises Técnicas Ltda. Rua Leão XIII, 281, 06296-180 Osasco, SP, Brazil. maressahnc@gmail.com, @ittp://orcid. org/0000-0002-9990-8283
} 
the diversity of habitat conditions, resulting in a more diverse biological community able to exploit the various niches (Ricklefs, Schluter, 1993).

The Atlantic Forest biome is one of the 25 global biodiversity hotspots (Myers et al., 2000) with levels of endemism of $90 \%$ for some organisms, which is surpassed only by Amazonia (Costa et al., 2000). Fish species richness is high and represented by 89 genera and 269 species of which $70 \%$ are endemic (Abilhoa et al., 2011). The percentage of fish species with restricted distribution is high in this ecosystem because of the great number of short and independent coastal river drainages and the unique basin characteristics squeezed between the mountains and the ocean (Bizerril, 1994; Menezes et al., 2007). However, most studies on species distributions in Atlantic Forest streams were conducted in Brazilian clear-waters (Rezende et al., 2010; Terra et al., 2013a, 2013b; Terra et al., 2016; Wolff, Hahn, 2017), which are typically high-gradient streams that form an intricate network of torrents and waterfalls (Por, 1992).

Blackwater streams represent important riverine habitats in the Atlantic Forest biome, but they have been poorly investigated up to now. They are slow-flowing streams which drain the alluvial plain of the Restinga Forest (Por, 1992), also called Coastal Plain Forest, which represents one of the faces of the Atlantic Forest biome (Marques et al., 2015). Blackwater streams are also rich in humic acids, having a dark color, low $\mathrm{pH}$, low nutrient content, and low species diversity of algae, invertebrates and fish, with a very specific ichthyofauna (Por, 1992). These aspects are shared with other blackwater rivers, such as the Amazonian Rio Negro (Gessner, 1964) and Malaysian rivers where the biomass of fish was only 0.5 g.m. $\mathrm{m}^{-2}$ compared to $18 \mathrm{~g} \cdot \mathrm{m}^{-2}$ observed in other non-blackwater rivers (Johnson, 1968).

Mesohabitats are subjectively defined as uniform and visually distinct habitat units (Armitage et al., 1995; Armitage, Pardo, 1995), resulting from the interaction between hydrological and geomorphological forces (Tickner et al., 2000; Jähnig et al., 2009). However, delimitation of boundaries between habitats corresponding with species distribution patterns is difficult because few examples can be found in nature where habitat boundaries are strictly demarcated (Pardo, Armitage, 1997). Visual evaluation of the distribution of mesohabitats gives us one method of defining the heterogeneity of the physical habitat of rivers, which is important for estimating biodiversity and making bioevaluations (Boyero, 2003; Kubíková et al., 2012).

The usefulness of mesohabitats as ecological study units has been shown, especially for macroinvertebrates and fishes (Buss et al., 2004; Reid, Thoms, 2008; Langeani et al., 2005; Rezende et al., 2010; Montaña, Winemiller, 2010; Mendes et al., 2017). For invertebrates, roots, macrophytes, marginal plants and inorganic substrates, such as silt, sand, gravel and cobblestone, are considered key mesohabitat components (Armitage, Cannan, 1998). For fish assemblages, different substrates (Montaña, Winemiller, 2010; Schwartz, 2016) and surface flows (riffles, glides, pools)
(Rezende et al., 2010; Kano et al., 2013; Schwartz, 2016; Wolff, Hahn, 2017) seem to influence species distribution. Many mesohabitat classification schemes present modifications to this basic terminology, even though delineation criteria remain essentially the same (Schwartz, 2016).

The amount of pools and depth in tropical streams depend on topographic gradients and substrates, suggesting that the size and types of mesohabitats vary according to their position in the river system. As small tributaries coalesce into higher-order streams, they become larger, but often less differentiated, particularly in low-gradient landscapes with deep alluvial substrates (Winemiller et al., 2008). Atlantic Rainforest blackwater streams belong to this category, having their origins at low altitude in the alluvial plain of the Serra do Mar of São Paulo State. Thus, in view of the particular conditions of low-flow rivers, the classification of mesohabitats for blackwater streams may follow different criteria from those adopted for other studies and can be based on water depth, visual turbulence, water velocity or substrate characteristics (Montaña, Winemiller, 2010; Schwartz, 2016).

Studies on the spatial patterns of the fish community in Neotropical blackwater streams are especially important because many studies have demonstrated high specificity between fish species composition and the mesohabitat scale that can be related to a species' life history, including evolutionary and behavioral processes, physiological and morphological mechanisms (Wootton, 1999). Other authors as Angermeier, Winston (1998) demonstrated that local fish species richness was better predicted by fish diversity within relatively small regions (e.g., physiographic units within river basins) than by fish diversity in larger regions (e.g., river basin), suggesting that local assemblages are affected by inter-stream connectivity and dispersal. Considering the peculiar conditions of blackwater streams, where mesohabitat configuration differs from their clear-water counterparts, at this study we aimed to 1) analyze whether different mesohabitats, including trunk, leaf-litter and sand, can be distinguished according to specific environmental features and 2) test whether species assemblage structure act as descriptors of these different mesohabitats types in blackwater streams.

\section{Material and Methods}

Study area. The Atlantic Forest covers the entire east coast of Brazil with vegetation consisting of Dense Ombrophylous Forest and Pioneer Formations, mangrove phytophysiognomies and restingas, all of which have been conserved in good condition in that portion of the Serra do Mar located in the State of São Paulo (Instituto Ekos Brasil, 2008).

The present study was carried out in the coastal region of São Paulo State in the Municipalities of Bertioga and São Sebastião, comprising the Conservation Unit "Restingas de Bertioga State Park" (PERB), a private area known 
as "Jimbuíbas Farm", and an area near the "Rio Silveira Indigenous Reserve" in the Municipality of São Sebastião (Fig. 1). PERB comprises a total of 9312.32 hectares out of which $98 \%$ are remnants of Restinga Forest. This forest is quite heterogeneous, both floristically and structurally, with distinct forms of vegetation, ranging from grasslands with a predominance of herbaceous plants, shrubs, and forest physiognomies, which feature a "complex" or "mosaic" of vegetation (Marques et al., 2015). The Restinga Forest typically occurs over the Brazilian coastal plains formed by marine sediments originated from the Quaternary (CONAMA, 1999).

According to Köppen (1948), the region's climate is classified as Af type, i.e., tropical with year-round rainfall and an annual mean temperature around $24^{\circ} \mathrm{C}$. It is one of the wettest regions in Brazil with an average annual rainfall of 3,200 $\mathrm{mm}$. The lowest average rainfall occurs in July (111 $\mathrm{mm})$ and the highest in February $(410 \mathrm{~mm})$. In the Municipality of São Sebastião, the average temperature recorded from April to September of 2016 was $18.33^{\circ} \mathrm{C}$ with cumulative precipitation of $593.06 \mathrm{~mm}$ (CIIAGRO, 2017).

For the present study, we sampled 14 blackwater streams, which belong to four subbasins: Itapanhaú, Itaguaré, Guaratuba and Una (Tab. 1). The criteria used for the selection of the sampling sites were accessibility, good conservation state and adequacy for sampling. The fieldwork occurred during the period of low rainfall (June-September/2016) and allowed the identification of 41 mesohabitats.

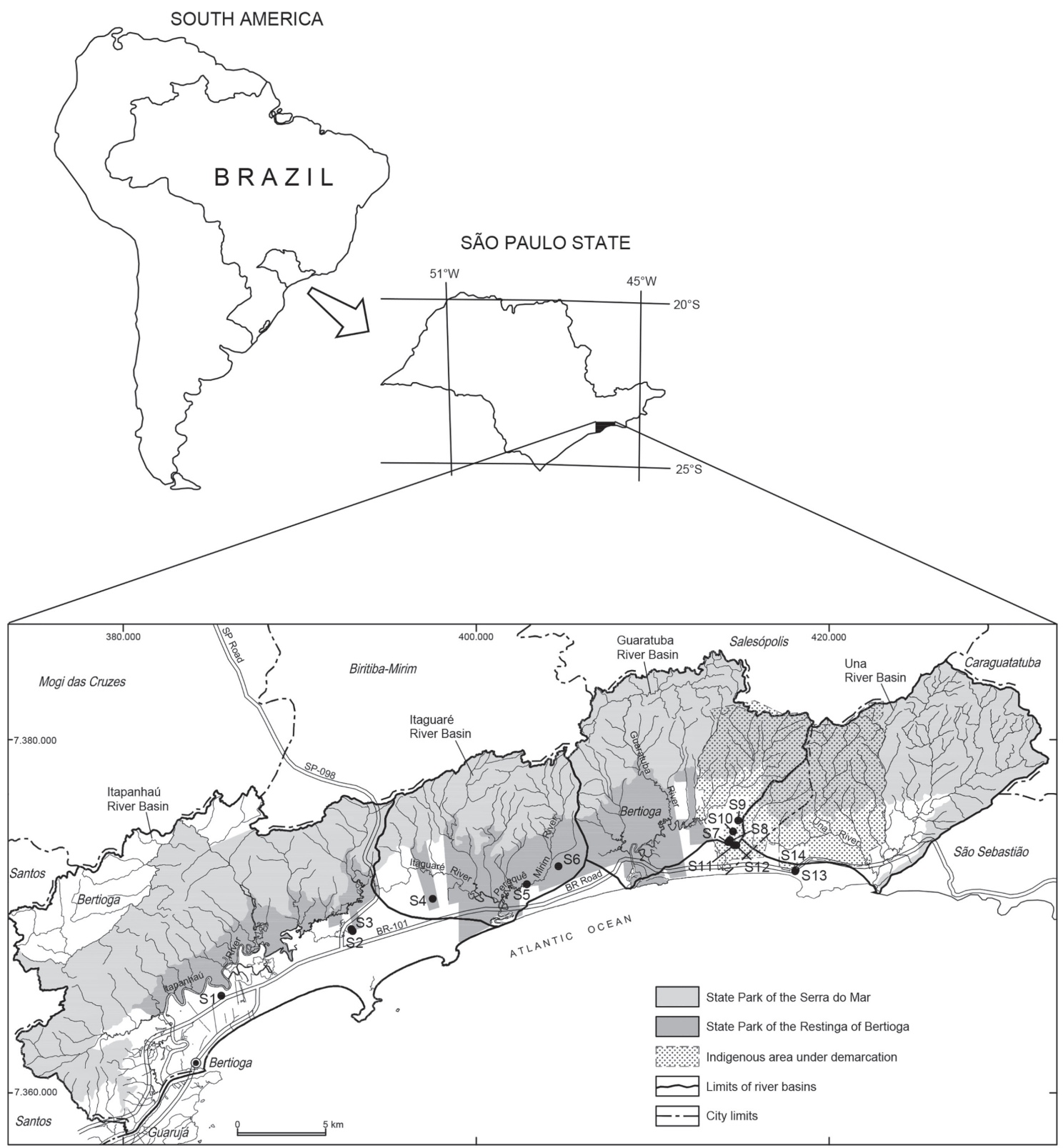

Fig. 1. Location of the study area in São Paulo State, showing the distribution of the sampling sites in the Itapanhaú, Itaguaré, Guaratuba and Una River subbasins located in the Municipalities of Bertioga and São Sebastião. 
Tab. 1. River Basins, catchment size (hectares), sampling locations and main characteristics of the sites located in the Municipalities of Bertioga and São Sebastião, SP. In bold, sites located within the Parque Estadual Restingas de Bertioga (PERB). HrDf - High Restinga Dry Forest; SF - Secondary Forest; $\mathrm{t}$ - tributary; * close to water supply pipes and/or road; ** close to small village. Vegetation types according to França, Rolim (2000); Girardi (2001) and Instituto Ekos Brasil (2008).

\begin{tabular}{|c|c|c|c|c|c|c|}
\hline Basin & $\begin{array}{l}\text { Catchment } \\
\text { Area (ha) }\end{array}$ & Stream & Acronym & $\begin{array}{l}\text { Dominant vegetation/ } \\
\text { Anthropic Influences }\end{array}$ & Coordinates & \\
\hline \multirow[t]{6}{*}{ Guaratuba } & 11.309 & Jimbuibas 1 & S7 & $\mathrm{HrDf} / \mathrm{SF}$ & S $23^{\circ} 44^{\prime} 27.1^{\prime \prime}$ & W 4550'28.5" \\
\hline & & Jimbuibas 2 & S8 & $\mathrm{HrDf} / \mathrm{SF}$ & S $23^{\circ} 44^{\prime} 23.7^{\prime \prime}$ & W 4550'24.6" \\
\hline & & Jimbuibas 3 & S9 & $\mathrm{HrDf} / \mathrm{SF}$ & S $23^{\circ} 43^{\prime} 47.6^{\prime \prime}$ & W 4550'07.9" \\
\hline & & Jimbuibas 4 & $\mathrm{~S} 10$ & $\mathrm{HrDf} / \mathrm{SF}$ & S $23^{\circ} 44^{\prime} 08.0^{\prime \prime}$ & W 4550'18.3" \\
\hline & & Jimbuibas 5 & S11 & $\mathrm{HrDf} / \mathrm{SF}$ & S $23^{\circ} 44^{\prime} 33.0^{\prime \prime}$ & W $45^{\circ} 50^{\prime} 16.8^{\prime \prime}$ \\
\hline & & Jimbuibas 6 & $\mathrm{~S} 12$ & $\mathrm{HrDf} / \mathrm{SF}$ & S $23^{\circ} 44^{\prime} 33.0^{\prime \prime}$ & W $45^{\circ} 50^{\prime} 11.8^{\prime \prime}$ \\
\hline \multirow[t]{3}{*}{ Itaguaré } & 9.040 & Maneco Pinto & S4 & Mixed Forest * & S $23^{\circ} 46^{\prime} 08.2^{\prime \prime}$ & W 460'ㄹ․ $20.4 "$ \\
\hline & & Perequê-Mirim (t) & S5 & Mixed Forest * & S $23^{\circ} 45^{\prime} 42.6^{\prime \prime}$ & W $45^{\circ} 57^{\prime} 11.8^{\prime \prime}$ \\
\hline & & Gumercindo & S6 & Mixed Forest ${ }^{* *}$ & S $23^{\circ} 45^{\prime} 09.9^{\prime \prime}$ & W $45^{\circ} 56^{\prime} 08.2^{\prime \prime}$ \\
\hline \multirow[t]{3}{*}{ Itapanhaú } & 14.900 & João Pereira 1 & S2 & Mixed Forest ${ }^{*}$ & S $23^{\circ} 47^{\prime} 06.6^{\prime \prime}$ & W $46^{\circ} 03^{\prime} 01.2^{\prime \prime}$ \\
\hline & & João Pereira 2 & S3 & Mixed Forest ${ }^{*}$ & S $23^{\circ} 47^{\prime} 03.0^{\prime \prime}$ & 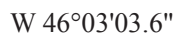 \\
\hline & & Vila Agaó & S1 & Mixed Forest ${ }^{* *}$ & S $23^{\circ} 49^{\prime} 03.8^{\prime \prime}$ & W $46^{\circ} 07^{\prime} 25.3^{\prime \prime}$ \\
\hline \multirow[t]{2}{*}{ Una } & 12.060 & Bora-Bora1 & S13 & Mixed Forest ${ }^{*}$ & $\mathrm{~S} 23^{\circ} 45^{\prime} 21.8^{\prime \prime}$ & W $45^{\circ} 48^{\prime} 14.6^{\prime \prime}$ \\
\hline & & Bora-Bora2 & S14 & Mixed Forest ${ }^{*}$ & S $23^{\circ} 45^{\prime} 19.4^{\prime \prime}$ & W 454ㅇ' $13.6^{\prime \prime}$ \\
\hline
\end{tabular}

Mesohabitat selection and measurements. For mesohabitat selection, we considered areas with different substrates within $100 \mathrm{~m}$ stretches of each river bed. The considered substrate categories were sand (coarse and fine), leaf-litter (heterogeneous litter from riparian vegetation) and trunks (small and large woody debris). Mesohabitat selection occurred by visual examination, adapting the methodology proposed by Montaña, Winemiller (2010), where the presence $\geq 75 \%$ of a particular substrate defined each mesohabitat type. After identification, we isolated the three mesohabitats in the $100 \mathrm{~m}$ stretch of river, using $5 \mathrm{~mm}$ mesh block nets.

For abiotic measurements, we divided each mesohabitat into three equidistant transects for the registration of width, depth, total length and the percentage of shading. For flow rate, we measured water velocity along a cross section at three depths, using a General Oceanics 2030R6 flowmeter, following Carvalho (2008) and Santos et al. (2001). When water velocity was very low, we used the float method (Marques, Argento, 1988) to provide an estimate of the maximum surface water velocity. For this calculation, we launched a float three times and measured the time required to pass through each mesohabitat.

Fish sampling. We carried out the fish collection with electrofishing equipment (HONDA EUi10 Generator, AC, 1000 watts). In each mesohabitat, we fished until no more individuals were captured. Fish were anesthetized in eugenol solution, fixed in $10 \%$ formalin solution, and transferred to $70 \%$ ethanol after 10 days. Specialists from the Museum of Zoology of the University of São Paulo (MZUSP) and the State University of Campinas (UNICAMP) confirmed fish identification.
Voucher specimens of Astyanax taeniatus (Jenyns, 1842) (ZUEC 16633), Hollandichthys multifasciatus (Eigenmann \& Norris, 1900) (ZUEC 16629), Hyphessobrycon griemi Hoedeman, 1957 (ZUEC 16637), Mimagoniates microlepis (Steindachner, 1877) (ZUEC 16632), Spintherobolus broccae Myers, 1925 (ZUEC 16636), Characidium lanei Travassos, 1967 (ZUEC 16630), Phalloceros harpagos Lucinda, 2008 (ZUEC 16638), Gymnotus pantherinus (Steindachner, 1908) (ZUEC 16631), Geophagus brasiliensis (Quoy \& Gaimard, 1824) (ZUEC 16641), Dormitator maculatus (Bloch, 1792) (ZUEC 16640), Scleromystax barbatus (Quoy \& Gaimard, 1824) (ZUEC 16635), Acentronichthys leptos Eigenmann \& Eigenmann, 1889 (ZUEC 16628), Cyphocharax santacatarinae (Fernández-Yépez, 1948) (ZUEC 17004), Rhamdia quelen (Quoy \& Gaimard, 1824) (ZUEC 16639), and Pseudotothyris obtusa (Miranda Ribeiro, 1911) (ZUEC 16634) were deposited in the Museu de Zoologia da Universidade Estadual de Campinas "Adão José Cardoso".

Data analysis. For environmental characterization, we considered data from all mesohabitats (41), while for fish assemblages, we included only data from 31 sites and 13 streams for which we had no-zero catches. To test if each identified mesohabitat (sand, leaf-litter and trunk) belonged to distinct groups based on their abiotic variables, we applied multivariate analysis of variance (MANOVA). Variables included in the MANOVA were length, mean width, mean depth, shading (percent) and water speed $\left(\mathrm{m} \cdot \mathrm{s}^{-1}\right)$. Variables that did not satisfy the assumptions of normality were normalized by $\log _{10}(\mathrm{x}+1)$ transformation prior to the analysis. Variables in percentages (i.e., shading) were arcsine $\sqrt{x / 100}$ transformed (Zar, 2010). 
To assess sampling efficiency, we calculated a sample-based rarefaction curve using Estimates software 9.1 (Colwell, 2013) with 100 randomizations. We used this procedure to compare similar fish assemblages collected with the same sampling method, but showing different richness and species abundance among the three mesohabitats. In agreement with Colwell (2013), rarefaction curves show the number of species in a survey as a function of the accumulated number of individuals or samples obtained by resampling of the observed data. Also, we estimated species richness for each mesohabitat using the non-parametric richness estimators Chao 1 (Colwell, Coddington, 1994) based on the number of rare species in a sample, such as singletons (number of species represented by single individual in a sample) and doubletons (number of species represented by two individuals in a sample) (Chao, 1987).

In order to standardize the fishing effort according to the sampled area in the following analysis, we transformed fish abundance and weight into density (ind. $\mathrm{m}^{-2}$ ) and biomass into g. $\mathrm{m}^{-2}$. Successively, we employed ANOSIM, a non-parametric analysis analogous to variance analysis and based on distance measure (Clarke, Gorley, 2006) to test the null hypothesis that the mesohabitat type did not influence the densities (n.ind. $\mathrm{m}^{-2}$ ) and biomass $\left(\mathrm{g} . \mathrm{m}^{-2}\right)$ of the species. We employed the Bray-Curtis distance as a measure of similarity, and data were previously transformed into $\log _{10}(\mathrm{x}+1)$. We realized this analysis with the statistical software PRIMER 6 (Clarke, Gorley, 2006).

To calculate community indexes of Simpson dominance $(\lambda)$, Shannon Diversity (H'), Pielou evenness' (J) (Krebs, 1999), and Margalef richness, we employed the PAST software, version 2.17 (Hammer et al., 2001). We examined the relationship between community indexes and environmental variables with a Redundancy Analysis (RDA) after performing a Detrended Correspondence Analysis (DCA) to distinguish between linear or unimodal species response. The DCA result indicated a linear species response (length of first DCA axis $<3$ S.D.) to the environmental gradient, allowing the use of the RDA. This is a canonical ordination technique, which explains variations in biotic attributes using a matrix of environmental variables, while also preserving the Euclidean distance among the objects (Legendre, Legendre, 2012).

Before performing the RDAs, we tested the environmental variables for multicollinearity through VIF (Variance Inflaction Factor). As all the variables showed VIF values $<5$, this problem was excluded because according to Gerbing (2014), multicollinearity is found when VIF $>5$. This analysis was performed on SPSS (SPSS Inc., 1998). We performed two other RDAs using species density and biomass, respectively, adopting the same procedures above. For these three RDAs we employed the CANOCO (version 4.5) software (ter Braak, Smilauer, 2002), centering and standardizing sample and species data previously. To test the significance of all canonical axes, we performed a Monte Carlo permutation under a reduced model (999 permutations).

\section{Results}

Physical habitat characteristics. Mesohabitat water speed was low, attaining maximum values of $0.21 \mathrm{~m} \cdot \mathrm{s}^{-1}$, while depth ranged from 1.4 to $43 \mathrm{~cm}$ and length from 1.80 to $15.0 \mathrm{~m}$. The ranges of width and shading were similar among mesohabitats, varying between 0.83 and $5.16 \mathrm{~m}$ and $5 \%$ and $95 \%$, respectively (Tab. 2). The multivariate analysis of variance (MANOVA) indicated no significant differences among the three mesohabitat typologies (Wilks' lambda $=$ $0.78 ; \mathrm{F}=0.78 ; \mathrm{P}=0.64$ ).

Tab. 2. Range of the environmental variables measured for each mesohabitat in 14 blackwater streams.

\begin{tabular}{lccc}
\hline & Sand & Leaf-litter & Trunks \\
\hline Length $(\mathrm{m})$ & $1.80-10.20$ & $2.82-8.50$ & $2.28-15.0$ \\
Width $(\mathrm{m})$ & $0.83-4.38$ & $1.16-3.16$ & $0.86-5.16$ \\
Depth $(\mathrm{cm})$ & $8.44-27.44$ & $1.47-43.39$ & $4.78-27.44$ \\
Speed $\left(\mathrm{m} . \mathrm{s}^{-1}\right)$ & $0.00-0.26$ & $0.00-0.13$ & $0.00-0.21$ \\
Shading $(\%)$ & $5.0-90.0$ & $10.0-90.0$ & $20.0-95.0$ \\
\hline
\end{tabular}

Ichthyofauna. We caught a total of 459 specimens in 31 mesohabitats, including 209 in the trunk mesohabitat, 195 in the leaf-litter mesohabitat and 55 in the sand mesohabitat. Total density was 0.58 ind. $\mathrm{m}^{-2}$ in sand mesohabitat, 2.27 ind. $\mathrm{m}^{-2}$ in leaf-litter, and 1.42 ind. $\mathrm{m}^{-2}$ in trunks. Of fifteen species recorded, M. microlepis was the most abundant (46.2\%). This species was present in all mesohabitats, showing the highest density in leaf-litter mesohabitats. The second most abundant species was the armored catfish $P$. obtusa (17.21\%) which showed high densities in trunks. The banded cory S. barbatus and H. multifasciatus were the third most abundant species (7.19\%), with highest densities in leaf-litter habitats (Tab. 3). Three species were exclusive of leaf-litter mesohabitat (the pearl cichlid $G$. brasiliensis, A. taeniatus and $C$. santacatarinae), while seven were common to the three mesohabitats (H. griemi, $C$. lanei, A.leptos, G. pantherinus, M. microlepis, P. harpagos and P. obtusa).

Rarefaction curves for the three mesohabitats suggested that an increase in the sampling effort might increase species richness, especially for sand and leaf-litter mesohabitats since individual-based curves did not reach a steady plateau (Fig. 2). As shown in Fig. 2, a plateau occurred for the trunk mesohabitat with 11 species. The non-parametric estimator of species richness Chao 1 confirmed this result, showing an expected number of species of 12 (CI ${ }_{\text {trunk }} 95 \%$ : 12.0 -13.5), close to the observed (11) for the trunk mesohabitat. For leaf-litter and sand mesohabitats, the expected richness was $13.2\left(\mathrm{CI}_{\text {leaf-litter } 95 \%}: 13.0-17.8\right)$ and 13 (CI sand $95 \%: 9.1-19.5)$, respectively. Both were higher than the observed, and the wider range of the confidence interval (CI) indicated that the increase of the sampling effort may improve the precision of the richness estimator in these mesohabitats. 
Fish communities in blackwater Atlantic Forest streams

Tab. 3. Population density, biomass $\left(\mathrm{g} \cdot \mathrm{m}^{-2}\right)$ and total abundance of individual fish species sampled in sand (S), leaf-litter (L) and trunk (T) mesohabitats in 13 blackwater streams in the subbasins of the Itapanhaú, Itaguaré, Guaratuba and Una Rivers located in the Municipalities of Bertioga and São Sebastião, São Paulo, Brazil.

\begin{tabular}{|c|c|c|c|c|c|c|c|c|c|c|c|}
\hline \multirow{2}{*}{ Order/Family } & \multirow{2}{*}{ Species } & \multirow[t]{2}{*}{ Species Acronym } & \multicolumn{3}{|c|}{ Density (ind. $\mathrm{m}^{-2}$ ) } & \multirow[t]{2}{*}{ Total abundance } & \multicolumn{3}{|c|}{ Biomass $\left(\mathrm{g} \cdot \mathrm{m}^{-2}\right)$} & \multicolumn{2}{|c|}{ Size range $(\mathrm{mm})$} \\
\hline & & & $\mathrm{T}$ & $\mathrm{L}$ & $\mathrm{S}$ & & $\mathrm{T}$ & $\mathrm{L}$ & $\mathrm{S}$ & & \\
\hline \multicolumn{12}{|l|}{ Characiformes } \\
\hline \multirow[t]{5}{*}{ Characidae } & Astyanax taeniatus & Aste & & 0.02 & & 2 & & & & 45 & 45 \\
\hline & Hollandichthys multifasciatus & Ноти & 0.09 & 0.23 & & 33 & 0.05 & 0.08 & & 17 & 95 \\
\hline & Hyphessobrycon griemi & Hygr & 0.01 & 0.09 & 0.01 & 11 & & & & 29 & 32 \\
\hline & Mimagoniates microlepis & Mimi & 0.55 & 1.22 & 0.28 & 212 & & 0.06 & 0.02 & 14 & 63 \\
\hline & Spintherobolus broccae & Spbr & 0.07 & 0.08 & & 17 & & & & 20 & 26 \\
\hline Crenuchidae & Characidium lanei & Chla & 0.07 & 0.08 & 0.04 & 22 & & 0.01 & & 30 & 60 \\
\hline Curimatidae & Cyphocharax santacatarinae & Cysa & & 0.01 & & 1 & & 0.02 & & 132 & $-\quad 132$ \\
\hline \multicolumn{12}{|c|}{ Cyprinodontiformes } \\
\hline Poeciliidae & Phalloceros harpagos & Pha & 0.02 & 0.02 & 0.02 & 7 & & & & 14 & 29 \\
\hline \multicolumn{12}{|l|}{ Gymnotiformes } \\
\hline Gymnotidae & Gymnotus pantherinus & Gypa & 0.01 & 0.08 & 0.02 & 11 & 0.03 & 0.11 & 0.07 & 96 & -205 \\
\hline \multicolumn{12}{|l|}{ Perciformes } \\
\hline Cichlidae & Geophagus brasiliensis & Gebr & & 0.02 & & 2 & & & & 28 & 50 \\
\hline Eleotridae & Dormitator maculatus & & 0.03 & & 0.01 & 5 & 0.02 & & & 31 & 75 \\
\hline \multicolumn{12}{|l|}{ Siluriformes } \\
\hline Callichthyidae & Scleromystax barbatus & $S c b a$ & 0.05 & 0.29 & & 33 & 0.01 & 0.12 & & 40 & 76 \\
\hline \multirow[t]{2}{*}{ Heptapteridae } & Acentronichthys leptos & Acle & 0.07 & 0.01 & 0.08 & 19 & 0.01 & & 0.03 & 36 & 80 \\
\hline & Rhamdia quelen & Rhqu & 0.03 & & 0.01 & 5 & 0.09 & & & 115 & $-\quad 152$ \\
\hline Loricariidae & Pseudotothyris obtusa & Psob & 0.42 & 0.09 & 0.09 & 79 & 0.01 & & & 27 & 41 \\
\hline $\mathrm{N}^{\circ}$ of species & & & 12 & 13 & 9 & & & & & & \\
\hline
\end{tabular}

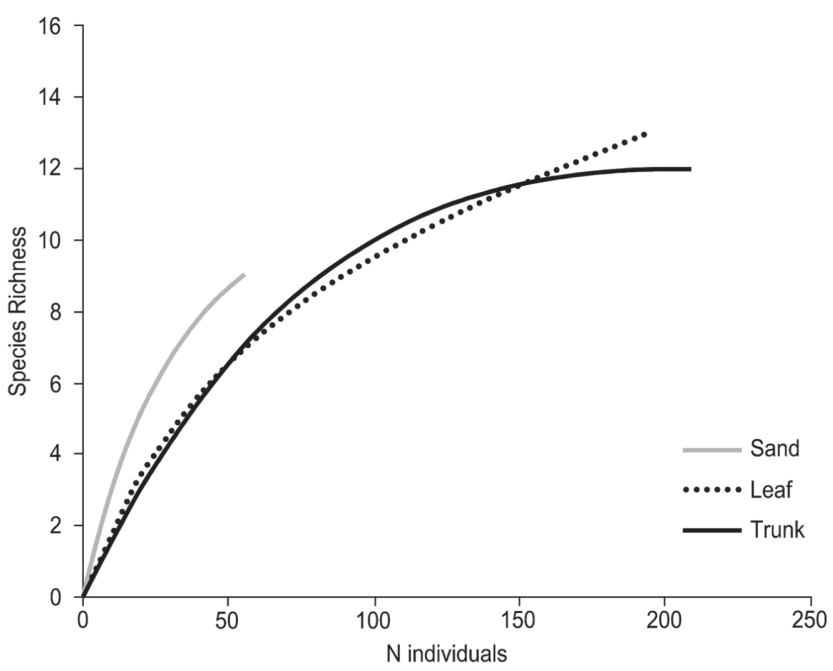

Fig. 2. Rarefaction curves calculated for each mesohabitat category (sand, leaf-litter and trunks), considering a total of 31 mesohabitats sampled in 13 blackwater streams of the alluvial plain of the Serra do Mar in the State of São Paulo. EstimateS 9.1 was used to plot species rarefaction curve (100 runs).

According to ANOSIM, no significant differences for species density $(\mathrm{R}=0.022, \mathrm{p}=0.28)$ and biomass $(\mathrm{R}=$ $0.056, \mathrm{p}=0.16$ ) were observed, indicating a high similarity among mesohabitats. The RDA performed on the species density matrix (Fig.3) produced eigenvalues of 0.063 and
0.056 for the first and second axes, respectively, and species-environment correlations of 0.580 and 0.567 , respectively. The first axis explained $33.9 \%$ of the variation, and the second axis explained $30.3 \%$. Axis 1 was associated with speed $(r=0.806)$ on the right half and shading on the negative side $(\mathrm{r}=-0.219)$. Axis 2 was mainly related to width $(\mathrm{r}=$ $0.858)$, length $(r=0.559)$ and depth $(r=0.455)$. The analysis revealed that some species, such as $M$. microlepis and $C$. la$n e i$, were associated with specific environmental conditions, such as a high percentage of shading and low water current. Pseudotothyris obtusa, G. brasiliensis and P. harpagos were associated with larger habitats, while $H$. griemi, $R$. quelen and $D$. maculatus were mainly related to lower shading habitats. The analysis did not reveal a clear mesohabitat separation, as confirmed by the non-significance of all canonical axes (F-ratio $=1.145 ; \mathrm{P}=0.308)$.

The RDA, applied to the species biomass, showed a similar pattern (Fig.4). In this case, the eigenvalues were 0.069 and 0.050 for the first two axes, respectively, and species-environment correlations were 0.683 and 0.634 , respectively. The first axis, which explained $37.8 \%$ of the variation, was associated with water speed $(\mathrm{r}=0.746)$, width $(\mathrm{r}=0.608)$ length $(\mathrm{r}=0.537)$ and depth $(0.488)$, while Axis 2 , which explained $27.7 \%$ of the variation, was associated with shading $(r=-0.713)$. Species association was similar to the anterior RDA, and, again, no clear pattern appeared among mesohabitats, as shown by the non-significance of all canonical axes (F-ratio $=1.115 ; \mathrm{P}=0.282)$. 


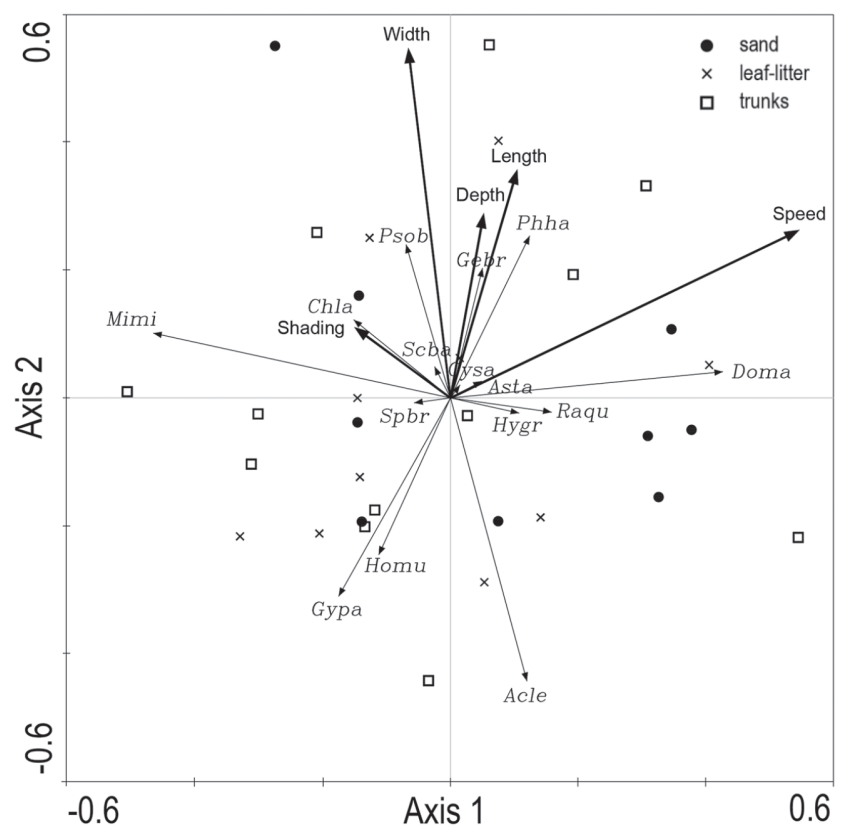

Fig. 3. RDA ordination biplot of the first and second RDA axes based on fish density (ind. $\mathrm{m}^{-2}$ ) of 31 blackwater mesohabitats. Vector lines in bold type indicate the relationship of the environmental variables to the ordination axis; the line's length is proportional to its relative significance. For species codes, see Tab. 3.

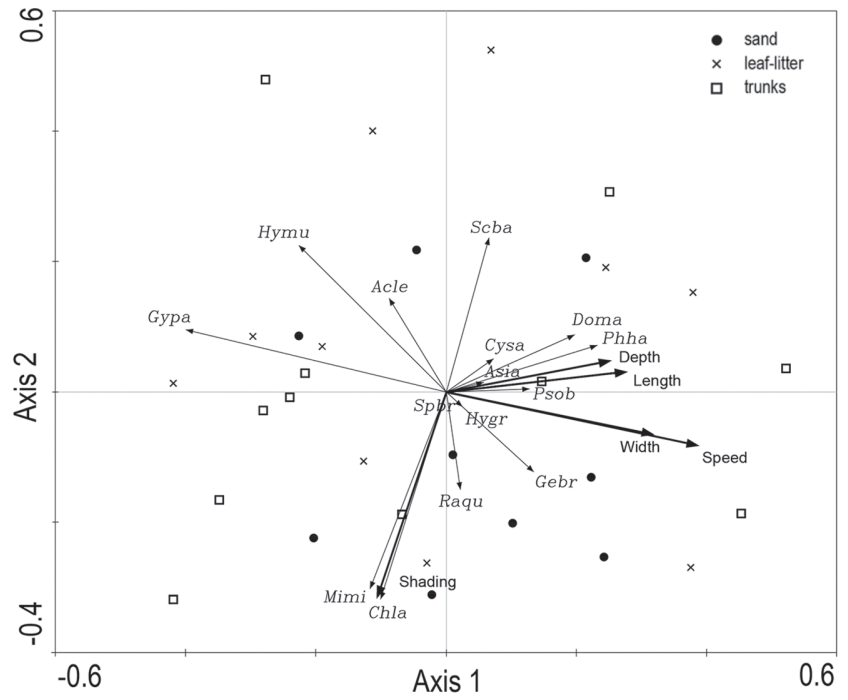

Fig. 4. RDA ordination biplot of the first and second RDAaxes based on fish biomass $\left(\mathrm{g} . \mathrm{m}^{-2}\right)$ of 31 blackwater mesohabitats. Vector lines in bold type indicate the relationship of the environmental variables to the ordination axis; the line's length is proportional to its relative significance. For species codes, see Tab. 3.

The RDA based on the community indexes for the three mesohabitats showed eigenvalues of 0.086 and 0.060 for the two first axes, respectively (Fig.5). The species-environment correlations for the two axes were 0.496 and 0.519 , respectively. The first axis explained $52.0 \%$ of the variation, and the second axis explained $36.6 \%$. The first RDA axis was associated with speed $(r=0.818)$, length $(r=0.746)$ and width $(\mathrm{r}=0.593)$, and the second RDA axis was associated with depth $(\mathrm{r}=0.558)$. Although no clear pattern for mesohabitat types was detected (significance of canonical axes: F-ratio $=0.990 ; \mathrm{P}=0.478$ ), Margalef's richness was inversely related to speed, length and shading, and the dominance was directly related to depth. Finally, many trunk and leaf-litter mesohabitats showed higher total fish biomass and density in association with lower depths, speed, shading and width.

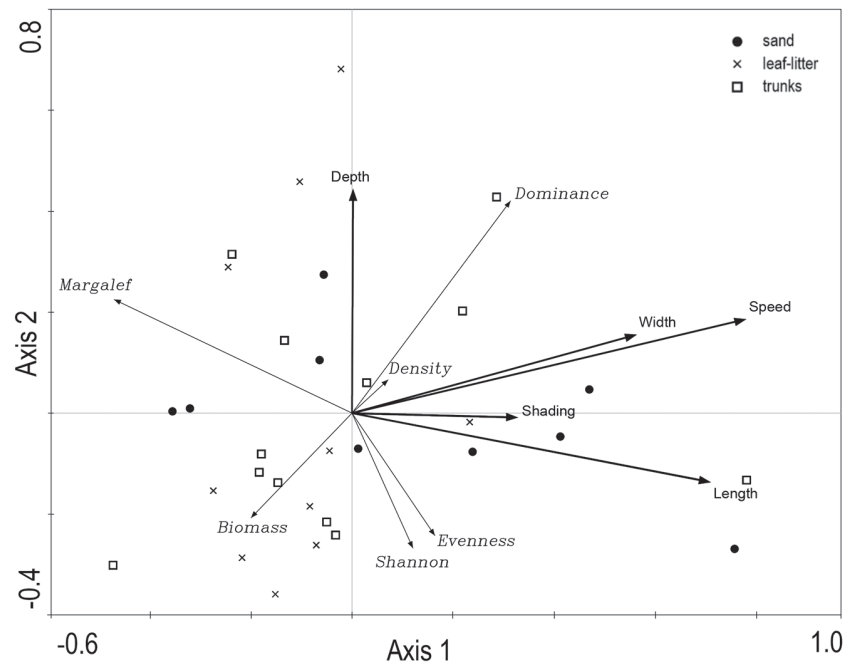

Fig. 5. RDA ordination biplot of the first and second RDA axes based on the fish community attributes of 31 blackwater mesohabitats. Vector lines in bold type indicate the relationship of the environmental variables to the ordination axis; the line's length is proportional to its relative significance.

\section{Discussion}

The 13 studied blackwater rivers showed low species diversity, homogeneity of mesohabitat conditions and high species dispersion among the three mesohabitat types. Although the structural complexity of rivers and streams can be understood as a mosaic of mesohabitats delimited by different combinations of current, depth and substrate composition (Angermeier, Schlosser, 1989), in the present study, we did not find any such differences in environmental conditions among the three mesohabitat typologies. These results differ from other studies performed in the Upper Paraná River Basin (Teresa, Casatti, 2012) and in whitewater Atlantic Forest streams (Rezende et al., 2010) where mesohabitats were generally classified based on surface water velocity (riffles, runs and pools). Our results indicate a remarkable homogeneity of conditions among the studied mesohabitats, at least during the low-water season when the samplings occurred. This also agrees with the observations of Winemiller et al. (2008), who found that mesohabitats become larger, but more similar, particularly in low-gradient landscapes. 
This environmental configuration can be analyzed from the perspective of the Patch Dynamics Concept, as described by Townsend (1989) and referenced above. This is true because a higher level of patchiness in streams has been associated with higher slopes and, hence, velocity, particulate matter accumulation and plant distribution (Pringle et al., 1988). In addition, the scale of patchiness and the nature of disturbances are different between headwaters and downstream segments (Townsend, 1989), affecting their use as refuge or for recolonization (Gjerløv et al., 2003). Other abiotic characteristics of the studied streams, such as low pH (3.7 - 6.3) and high Dissolved Organic Carbon (DOC) (9.9 - $85.8 \mathrm{mg}^{-1}{ }^{-1}$ (Silva, 2017), indicated the high contribution of humic substances in these systems. In fact, as reported in the literature, $\mathrm{pH}$ may influence fish organization in blackwater streams (Gonçalves, Braga, 2012), while humic substances protect freshwater fish against ionoregulatory disturbances associated with acute low pH (Duarte et al., 2016).

Ichthyofauna. The number of species found (15) was lower than that recorded in another study of four blackwater restinga rivers in the State of São Paulo (21) (Ferreira, 2007), but similar to the results obtained by Gonçalves, Braga (2012) for the Ribeira de Iguape River, a coastal plain river of the eastern lowlands (12). These results confirm the view that these acidic blackwater streams hold an impoverished ichthyofauna as often stated in the literature (Por, 1992; Lowe-McConnell, 1999).

The comparison among rarefaction curves for mesohabitat types indicated that the sampling effort was effective only for the trunk. This could be explained by the fact that this habitat provides appropriate substratum and structural condition to satisfy multiple functional purposes as feeding, refuge and reproduction for fishes (Matthews, 1998). In fact, the accumulation of large woody debris has been identified as a fundamental habitat for fishes throughout various stages in their lifecycle (Gibbons, 1990), resulting in many beneficial effects, especially in lowland rivers (Nagayama et al., 2012). On the other hand, sand and leaf mesohabitats are probably habitats temporarily explored by the ichthyofauna, thus suggesting the necessity of a more consistent sampling effort. These observations are in agreement with Zuanon et al. (2006) who described sandy mesohabitats as structurally very simple. They are also considered unstable habitats and generally avoided by many invertebrates, thus resulting in fewer food sources for fish (Krynak, 2012). Furthermore, the ability to inhabit sandy areas requires a set of highly specialized ecological characteristics, and few species exclusively occupy this type of habitat (Schaefer et al., 2005). In fact, species recorded in the sand mesohabitat, such as $S$. barbatus, A. leptos, $R$. quelen and P. obtusa, do not present any adaptations for psammophily, an ability to inhabit sandy areas, which is more common in the northern region of South America (Carvalho et al., 2013).

The set of results obtained by the ANOSIM and RDA ordinations for density, biomass and community indexes indi- cated no differences among mesohabitats. This result stands in contrast to similar studies performed in other Neotropical rivers (Bürnheim, Cox Fernandes, 2003; Langeani et al., 2005; Rezende et al., 2010; Wolff, Hahn, 2017) which compared pool versus riffle and run fish species. In general, these studies identified higher richness in pools, as specifically related to greater depth and slower current, while riffles were considered least hospitable because of the large amounts of energy that fish must expend to keep themselves positioned against the current (Power, 1984). Our results also differ from studies in analogous blackwater Amazonian streams where fish species have highly localized distributions within litter banks, living in very restricted regions during the dry season (Henderson, Walker, 1990). However, our results were similar to those obtained by Montaña, Winemiller (2010) who examined cichlid fish diversity in a blackwater floodplain river in Venezuela, finding high overlap in the assemblage structure between mesohabitat patches. This floodplain river undergoes gradual and predictable seasonal water-level fluctuations (Montoya et al., 2006), forcing fishes of the littoral zone to move frequently to new patches (Montaña,Winemiller, 2010).

Although hydrological conditions of the studied rivers are different from those observed in floodplains, field observations showed that the river level may vary up to two meters during the year, indicating that the communities are seasonally subject to some level of disturbance. Recalling the statement of Townsend (1989), disturbance plays an important role in structuring communities and may affect the value of patches as refugia. Refuge size, disturbance intensity, and mobility of organisms are all predicted to play a predominant role in population persistence and population dynamics of fishes using refugia during drought (Magoulick, Kobza, 2003). Thus disturbance might remove all individuals from a patch, but some local populations likely persist because of the mass effect, a continuous or periodic influx of individuals from adjacent or distant habitats (Schmida, Wilson, 1985). Although samplings occurred during the dry season, when the water level was low, this model might explain the similarity in population structure observed among mesohabitats, indicating that dispersion can be an important process, especially in a small scale. It can also represent an opportunistic strategy, which may be important in maximizing the rate of population increase, especially in these blackwater rivers where population densities are very low (Silva, 2017).

Despite the similarity of fish density and biomass between mesohabitats, the RDA showed that some species, such as M. microlepis and C. lanei, were associated with some particular environmental conditions like low flow and shaded habitats. This can be explained by the behavior of the first species, considered an insectivorous surface feeder, which forms shoals usually associated with deep pools, low water flow and under overhanging trees (Esteves, Lobón-Cerviá, 2001). Characidium lanei is also an insectivorous species (Aranha et al., 2000) and thus may benefit from insect larvae associated with the river bottom. On the other hand, D. maculatus was 
associated with higher water velocity, which may be related to its amphidromous habit, essentially because this species migrates between freshwater and the estuary (Riede, 2004). Hollandichthys multifasciatus and G. pantherinus occurred in shallow areas, as also observed in clearwater Atlantic Forest Rivers, where these species are usually associated with vegetation along river banks (Esteves, Lobón-Cerviá, 2001).

A similar pattern of community structure among mesohabitats in this study seems to reflect the above-mentioned dispersion and patch occupation processes. However, higher biomass, Shannon diversity and Margalef's richness were, to some extent, associated with particular environmental features, such as low shading and shallow habitats. In fact, changes in riparian canopy can affect communities by influencing cover, habitat, instream temperature, and primary production (Bojsen, Barriga, 2002), increasing fish biomass. This agrees with Esteves et al. (2008) who examined the lower course of a stream from the Paraná River Basin and observed an increase of biomass and richness for several fish families at open pasture sites characterized by open canopy, high water speed and high sinuosity.

Richness has been associated with habitat size and increased habitat heterogeneity, as reported for Panamanian streams (Angermeier, Schlosser, 1989) and French Guiana streams (Mérigoux et al., 1998). Our study found an inverse relationship between richness and biomass and mesohabitat length, speed, width and depth. This situation may be explained by the unique characteristics of these acidic blackwater streams where food webs are heavily reliant on the input of large amounts of organic matter from the surrounding terrestrial environment (Holland et al., 2012). During the dry season, allochthonous inputs are low, as also observed in other studies (Prejs, Prejs, 1987; Esteves, Galetti Jr, 1995); therefore, we suggest that during the dry season, fish would occupy the most productive patches, such as shallow open areas where primary production and, consequently, invertebrate biomass would be higher. These environmental features apparently occurred in several trunk and leaf-litter mesohabitats, suggesting that the abundance of producers and macroinvertebrates was higher at these sites. Similar findings were observed for deforested Ecuadorian streams where omnivorous or insectivorous fishes became more abundant at the deforested sites because of the increase in macroinvertebrate density (Bojsen, Barriga, 2002).

To summarize, in the studied alluvial plain blackwater streams, our results show that community is uniformly distributed among mesohabitats during the dry season. In agreement with Arrington et al. (2005), the occupation of patches may result from dispersion processes, suggesting that fish assemblages are continuously disassembled and reassembled, as organisms vacate and recolonize patches, especially during the water level recession period. Fine-scale environmental factors, such as depth, shading and water flow influenced the distribution of some species likely searching for more favorable conditions during this period of low food availability.

\section{Acknowledgements}

This work was supported by the Fundação de Amparo à Pesquisa do Estado de São Paulo (Proc. 2015/26728-6) which provided a scholarship to MHNC (Proc. 2016/09085-7) and the Coordenação de Aperfeiçoamento de Pessoal de Nível Superior which provided a scholarship to MHCS (Code 001). The authors thank Sergio Luiz da Silva, Ronaldo de Flores Bernardino, Luiz Evangelista and Renato Horikoshi Candido da Silva for help in the field- work; João Batista Pinheiro da Silva, Marizete Ramos dos Santos and Bolivar Barbanti, who assisted during the collections; Oswaldo Oyakawa and Flávio C. Lima for help in identifying the fish species; Mirna Ferracini for map drawing; the Peralta group for allowing us to perform part of the study on their property; the Forestry Institute of São Paulo State (SMA Process: 260108-003286/2016) and the Sistema de Autorização e Informação em Biodiversidade ( $\mathrm{N}^{\circ}$ 54432-1) for the sampling license.

\section{References}

Abilhoa V, Braga RR, Bornatowski H, Vitule JRS. Fishes of the Atlantic Rain Forest streams: ecological patterns and conservation [Internet]. Croatia: InTech; 2011. Chapter 12, Changing diversity in changing environment. [cited 25 November 2017]. Available from: https://www.intechopen.com/books/changingdiversity-in-changing-environment/fishes-of-the-atlantic-rainforest-streams-ecological-patterns-and-conservation

Angermeier PL, Schlosser IJ. Species-area relationships for stream fishes. Ecology. 1989; 70(5):1450-62.

Angermeier PL, Winston MR. Local vs. regional influences on local diversity in stream fish communities of Virginia. Ecology. 1998; 79(3):911-27.

Aranha JMR, Gomes JHC, Fogaça FNO. Feeding of two sympatric species of Characidium, C. lanei and C. pterostictum (Characidiinae) in a coastal stream of Atlantic Forest (Southern Brazil). Braz Arch Biol Technol. 2000; 43(5):527-31.

Armitage PD, Cannan CE. Nested multi-scale surveys in lotic systems: tools for management. In: Bretschko G, Helesic J, editors. Advances in river bottom ecology. Leiden: Backhuys Publishers; 1998. p.293-314.

Armitage PD, Pardo I. Impact assessment of regulation at the reach level using macroinvertebrate information from mesohabitats. River Res Appl. 1995; 10(2-4):147-58.

Armitage PD, Pardo I, Brown A. Temporal constancy of faunal assemblages in 'mesohabitats'-application to management? Arch Hydrobiol. 1995; 133(3):367-87.

Arrington DA, Winemiller KO, Layman CA. Community assembly at the patch scale in a species-rich tropical river. Oecologia. 2005; 144(1):157-67.

Bizerril CRSF. Análise taxonômica e biogeográfica da ictiofauna de água doce do leste brasileiro. Acta Biol Leopold. 1994; 16(1):51-80.

Bojsen BH, Barriga R. Effects of deforestation on fish community structure in Ecuadorian Amazon streams. Freshwater Biol. 2002; 47(11):2246-60. 
Boyero L. The quantification of local substrate heterogeneity in streams and its significance for macroinvertebrates assemblages. Hydrobiologia. 2003; 499(1-3):161-68.

ter Braak CJF, Smilauer P. CANOCO Reference manual and CanoDraw for Windows user's guide: Software for Canonical Community Ordination (version 4.5). Ithaca, NY, USA: Microcomputer Power; 2002.

Bührnheim CM, Cox Fernandes C. Structure of fish assemblages in Amazonian Rain Forest streams: effects of habitats and locality. Copeia. 2003; 2003(2):255-62.

Buss DF, Baptista DF, Nessimian JL, Egler M. Substrate specificity, environmental degradation and disturbance structuring macroinvertebrate assemblages in neotropical streams. Hydrobiologia. 2004; 518(1-3):179-88.

Carvalho MS, Zuanon J, Ferreira EJG. Diving in the sand: the natural history of Pygidianops amphioxus (Siluriformes: Trichomycteridae), a miniature catfish of Central Amazonian streams in Brazil. Environ Biol Fish. 2013; 97(1):59-68.

Carvalho TM. Técnicas de medição de vazão por meios convencionais e não convencionais. Revista Brasileira de Geografia Física. 2008; 1(1):73-85.

Centro Integrado de Informações de Agronegócios (CIIAGRO). Portal agrometeorológico e hidrológico do Estado de São Paulo [Internet]. 2017 [updated 2017]. Available from: http://www.ciiagro.org.br

Chao A. Estimating the population size for capture-recapture data with unequal catchability. Biometrics. 1987; 43(4):783-91.

Clarke KR, Gorley RN. PRIMER v6: user manual/tutorial. United Kingdom: PRIMER-E, Plymouth; 2006.

Colwell RK. EstimateS 9.0: Statistical estimation of species richness and shared species from samples. Storrs: University of Connecticut; 2013.

Colwell RK, Coddington JA. Estimating terrestrial biodiversity through extrapolation. Philol Trans R Soc Lond B Biol Sci. 1994; 345(1311):101-18.

Conselho Nacional do Meio Ambiente (CONAMA). Resolução 261, de 30 de junho de 1999. [Internet]. 1999 [updated 2018 Aug]. Available from: http://www.mma.gov.br/port/conama/res/res99/ res26199.html

Costa LP, Leite YLR, da Fonseca GAB, da Fonseca MT. Biogeography of South American forest mammals: endemism and diversity in the Atlantic Forest. Biotropica. 2000; 32(4b):872-81.

Duarte RM, Scott Smith D, Val AL, Wood CM. Dissolved organic carbon from the upper Rio Negro protects zebrafish (Danio rerio) against ionoregulatory disturbances caused by low $\mathrm{pH}$ exposure. Sci Rep. 2016; 6:20377[10p.].

Esteves KE, Galetti Jr PM. Food partitioning among some characids of a small Brazilian floodplain lake from the Paraná River basin. Env Biol Fish. 1995; 42(4):375-89.

Esteves KE, Lobo AVP, Faria MDR. Trophic structure of a fish community along environmental gradients of a subtropical river (Paraitinga River, upper Tietê River basin, Brazil). Hydrobiologia, 2008; 598(1):373-87.

Esteves KE, Lobón-Cerviá J. Composition and tropic structure of a fish community of a clear water Atlantic rainforest stream in southeastern Brazil. Environ Biol Fish. 2001; 62(4):429-40.
Ferreira FC. Ictiofauna de riachos na planície costeira da bacia do rio Itanhaém, litoral sul de São Paulo. [MSc Dissertation on the Internet]. Rio Claro: Universidade Estadual Paulista; 2007. Available from: http://hdl.handle.net/11449/99497

França FS, Rolim SG. Estrutura de um trecho de floresta de restinga no município de Bertioga (SP). In: Anais do V Simpósio de Ecossistemas Brasileiros: Conservação, vol 3. São Paulo: ACIESP; 2000. p.84-91.

Gerbing DW. 2014: R data analysis without programming. 1st ed. New York: Taylor, Francis; 1994.

Gessner F. The limnology of tropical rivers. Verh Internat Verein Limnol. 1964; 15(2):1090-91.

Gibbons DR. Fish in the forest: large woody debris in streams a new management approach to fish habitat. Alaska (USA): U.S. Department of Agriculture, Forest Service; 1990.

Girardi ACS. Subsídios metodológicos para o planejamento e gestão de restingas: estudo de caso - Bertioga. [MSc Dissertation]. São Paulo, SP: Universidade de São Paulo; 2001.

Gjerløv C, Hildrew AG, Jones JI. Mobility of stream invertebrates in relation to disturbance and refugia: a test of habitat template theory. J N Am Benthol Soc. 2003; 22(2):207-23.

Gonçalves CS, Braga FMS. Changes in ichthyofaunal composition along a gradient from clearwaters to blackwaters in coastal streams of Atlantic forest (southeastern Brazil) in relation to environmental variables. Neotrop Icthyol. 2012; 10(3):675-84.

Hammer $\varnothing$, Harper DAT, Ryan PD. PAST: Paleontological statistics software for education and data analysis. Palaeontologia Electronica. 2001; 4(1):[9p].

Henderson PA, Walker I. Spatial organization and population density of the fish community of the litter banks within a central Amazonian blackwater stream. J Fish Biol. 1990; 37(3):401-11.

Holland A, Duivenvoorden LJ, Kinnear SHW. Naturally acidic waterways: conceptual food webs for better management and understanding of ecological functioning. Aquat Conserv. 2012; 22(6):836-47.

Instituto Ekos Brasil. Diagnóstico socioambiental para criação de unidades de conservação polígono Bertioga: relatório final. [Internet]. 2008 [updated 2017 Dec]. Available from: http://assets.wwfbr.panda.org/downloads/diagnostico_socioambiental_para_criacao_de_unidades_de_conservacao.pdf

Jähnig S, Lorenz A, Hering D. Restoration effort, habitat mosaics, and macroinvertebrates - does channel form determine community composition?. Aquat Conserv. 2009; 19(2):157-69.

Johnson DS. Malayan blackwaters. In: Misra R, Gopal B. Proceedings of the symposium on recent advances in tropical ecology. Varanasi: International Society for Tropical Ecology; 1968. p.303-310.

Kano Y, Miyazaki Y, Tomiyama Y, Mitsuyuki C, Nishida S, Rashid ZA. Linking mesohabitat selection and ecological traits of a fish assemblage in a small tropical stream (Tinggi River, Pahang Basin) of the Malay Peninsula. Zool Sci. 2013; 30(3):178-84. 
Köppen W. Climatología: com un estudio de los climas de la tierra. México: Fondo de Cultura Econômica; 1948.

Krebs CJ. Ecological Methodology. 2nd ed. New York: AddisonWesley Educational Publishers, Inc; 1999.

Krynak EM. Aquatic mesohabitats: abiotic and biotic comparisons in a sand-dominated, 3rd order, Michigan stream. [MSc Dissertation on the Internet]. Michigan: Grand Valley State University; 2012. Available from: Grand Valley State University. https://scholarworks.gvsu.edu/cgi/viewcontent. cgi?referer=https://www.google.com.br/\&httpsredir=1\&artic $1 \mathrm{e}=1032 \&$ context $=$ theses

Kubíková L, Simon OP, Tichá K, Douda K, Maciak M, Bílý M. The influence of mesoscale habitat conditions on the macroinvertebrate composition of springs in a geologically homogeneous area. Freshw Sci. 2012; 31(2):668-79.

Langeani F, Casatti L, Gameiro HS, Carmo AB, Rossa-Feres DC. Riffle and pool fish communities in a large stream of southeastern Brazil. Neotrop Icthyol. 2005; 3(2):305-11.

Legendre P, Legendre L, editors. Numerical ecology, volume 24. 3rd ed. Amsterdam: Elsevier Science; 2012.

Leibold MA, Holyoak M, Mouquet N, Amarasekare P, Chase JM, Hoopes MF, Holt RD, Shurin JB, Law R, Tilman D, Loreau M, Gonzalez A. The metacommunity concept: a framework for multi-scale community ecology. Ecol Lett. 2004; 7(7):601-13.

Lowe-McConnell RH. Estudos ecológicos de comunidades de peixes tropicais. São Paulo: EDUSP; 1999.

Magoulick DD, Kobza RM. The role of refugia for fishes during drought: A review and synthesis. Freshwater Biol. 2003; 48(7):1186-98.

Marques JS, Argento MSF. O uso de flutuadores para avaliação da vazão de canais fluviais. Geociências. 1988; 7(1):173-86.

Marques MCM, Silva SM, Liebsch D. Coastal plain forests in southern and southeastern Brazil: ecological drivers, floristic patterns and conservation status. Braz J Bot. 2015; 38(1):1-18.

Matthews WJ. Patterns in freshwater fish ecology. New York: Chapman \& Hall; 1998.

Mendes F, Kiffer WP, Moretti MS. Structural and functional composition of invertebrate communities associated with leaf patches in forest streams: a comparison between mesohabitats and catchments. Hydrobiologia. 2017; 800(1):115-27.

Menezes NA, Weitzman SH, Oyakawa OT, Lima FCT, Castro RMC, Weitzman MJ, editors. Peixes de água doce da Mata Atlântica: lista preliminar das espécies e comentários sobre conservação de peixes de água doce neotropicais. São Paulo: Museu de Zoologia da Universidade de São Paulo; 2007.

Mérigoux S, Ponton D, Mérona B. Fish richness and specieshabitat relationships in two streams of French Guiana, South America. Environ Biol Fish. 1998; 51(1):25-39.

Montaña CG, Winemiller KO. Local-scale habitat influences morphological diversity of species assemblages of cichlid fishes in a tropical floodplain river. Ecol Freshw Fish. 2010; 19(2):216-27.

Montoya JV, Roelke D, Winemiller KO, Cotner JB, Snider J. Hydrological seasonality and benthic algal biomass in a neotropical floodplain river. J N Am Benthol Soc. 2006; 25(1):157-70.
Myers NRA, Mittermeier RA, Mittermeier CG, Fonseca GAB, Kent J. Biodiversity hotspots for conservation priorities. Nature. 2000; 403(6772):853-58.

Nagayama S, Nakamura F, Kawaguchi Y, Nakano D. Effects of configuration of instream wood on autumn and winter habitat use by fish in a large remeandering reach. Hydrobiologia. 2012; 680(1):159-70.

Pardo I, Armitage PD. Species assemblages as descriptors of mesohabitats. Hydrobiologia. 1997; 344(1-3):111-28.

Por FD. Sooretama, the Atlantic Rain Forest of Brazil. Hague, The Netherlands: SPB Academic Publishing; 1992.

Power ME. Depth distributions of armored catfish: predator-induced resource avoidance? Ecology. 1984; 65(2):523-28.

Prejs A, Prejs K. Feeding of tropical freshwater fishes: seasonality in resource availability and resource use. Oecologia 1987; 71(3):397-404.

Pringle CM, Naiman JR, Bretschko G, Karr JR, Oswood MW, Webster JR, Welcomme RL, Winterbourn MJ. Patch dynamics in lotic systems: the stream as a mosaic. J N Am Benthol Soc. 1988; 7(4):503-24.

Reid MA, Thoms MC. Surface flow types, near-bed hydraulics and the distribution ofstream macroinvertebrates. Biogeosciences Discuss. 2008; 5:1043-55.

Rezende CF, Moraes M, Manna LR, Leitão RP, Caramaschi EP, Mazzoni R. Mesohabitat indicator species in a coastal stream of the Atlantic rainforest, Rio de Janeiro-Brazil. Rev Biol Trop. 2010; 58(4):1479-87.

Ricklefs RE, Schluter D. Species diversity: regional and historical influences. In: Ricklefs RE, Schluter D, editors. Species diversity in ecological communities: historical and geographical perspectives. Chicago: University of Chicago Press; 1993. p.350-363.

Riede K. Global register of migratory species - from global to regional scales. Bonn: Federal Agency for Nature Conservation; 2004.

Santos I, Fill HD, Sugai MRVB, Buba H, Kishi RT, Marone D, Lautert LF, editors. Hidrometria Aplicada. Curitiba: LACTEC; 2001.

Schaefer SA, Provenzano F, de Pinna MCC, Baskin JN. New and noteworthy Venezuelan Glanapteryginae catfishes (Siluriformes, Trichomycteridae), with discussion of their biogeography and psammophily. Am Mus Novit. 2005; 9(3496):1-27.

Schmida A, Wilson MV. Biological determinants of species diversity. J Biogeogr. 1985; 12(1):1-20.

Schwartz JS. Use of ecohydraulic-based mesohabitat classification and fish species traits for stream restoration design. Water. 2016; 8(11):520[33p.].

Silva MHC. Organização da comunidade de peixes em riachos de água preta de Mata Atlântica. [MSc Dissertation]. São Paulo, SP: Instituto de Pesca; 2017.

SPSS Inc. SPSS Base 8.0 for Windows user's guide. Chicago, IL, USA: SPSS Inc; 1998.

Teresa FB, Casatti L. Influence of forest cover and mesohabitat types on functional and taxonomic diversity of fish communities in Neotropical lowlands streams. Ecol Freshw Fish. 2012; 21(3):433-42. 
Fish communities in blackwater Atlantic Forest streams

Terra BDF, Hughes RM, Francelino MR, Araújo FG. Assessment of biotic condition of Atlantic Rain Forest streams: a fish-based multimetric approach. Ecol Indic. 2013a; 34:136-48.

Terra BF, Hughes RM, Araújo FG. Sampling sufficiency for fish assemblage surveys of tropical Atlantic Forest streams, southeastern Brazil. Fisheries. 2013b; 38(4):150-58.

Terra BF, Hughes RM, Araújo FG. Fish assemblages in Atlantic Forest streams: the relative influences of local and catchment environments on taxonomic and functional species. Ecol Freshw Fish. 2016; 25(4):527-44.

Tickner D, Armitage PD, Bickerton MA, Hall KA. Assessing stream quality using information on mesohabitat distribution and character. Aquat Conserv. 2000; 10(3):179-96.

Townsend CR. The patch dynamics concept of stream community ecology. J N Am Benthol Soc. 1989; 8(1):36-50.

Wang L, Lyons J, Rasmussen P, Seelbach P, Simon T, Wiley M, Kanehl P, Baker E, Niemela S, Stewart PM. Watershed, reach, and riparian influences on stream fish assemblages in the Northern Lakes and Forest Ecoregion, USA. Can J Fish Aquat Sci. 2003; 60(5):491-505.

Winemiller KO, Agostinho AA, Caramaschi EP. Fish ecology in tropical streams. In: Dudgeon D, editor. Tropical stream ecology. Academic Press; 2008. p.107-146.
Winemiller KO, Flecker AS, Hoeinghaus DJ. Patch dynamics and environmental heterogeneity in lotic ecosystems. J N Am Benthol Soc. 2010; 29(1):84-99.

Wolff LL, Hahn NS. Fish habitat associations along a longitudinal gradient in a preserved coastal Atlantic stream, Brazil. Zoologia. 2017; 34:e12975[13p.].

Wootton RJ. Ecology of teleost fishes. 2nd ed. Springer Netherlands; 1999.

Zar JH. Biostatistical Analysis. 5th ed. Upper Saddle River (NJ): Pearson Prentice-Hall; 2010.

Zuanon J, Bockmann FA, Sazima I. A remarkable sand-dwelling fish assemblage from central Amazonia, with comments on the evolution of psammophily in South American freshwater fishes. Neotrop Ichthyol. 2006; 4(1):107-18. 